研究

\title{
絶緑被覆鉄粉を用いた複合軟磁性材料の腐食特性
}

\author{
砂田 聡的 1 , 伊井 雅一放 2 , 森本耕一郎祙 3 , 真島 一彦的 1 \\ 1 1 富山大学大学院理工学研究部, ₹ 930-8555 富山市五福 3190.

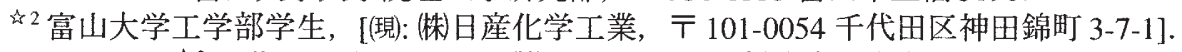 \\ 丸3 三菱マテリアル PMG (侏)， テ 950-8640 新潟市小金町 3-1-1。
}

\section{Corrosion Characteristics of Iron Soft Magnetic Composites Coated with Insulation Film}

\author{
Satoshi Sunada ${ }^{\text {1 }}$, Masakazu Ii ${ }^{2}$, Koichiro Morimoto ${ }^{3}$ and Kazuhiko Majima \\ ${ }^{21}$ Graduate School of Science and Engineering for Research, University of Toyama, 3190 Gofuku, Toyama 930-8555, Japan. \\ ${ }^{2}$ Undergraduate Student, University of Toyama, \\ [Present Address: Nissan Chemical Industries, Itd, 1-1-1 Kandanisiki-cho, Chiyoda-ku, Tokyo 101-0054, Japan]. \\ ${ }^{4}$ Mitsubishi materials PMG corporation, 3-1-1 Kogane-cho, Niigata 950-8640, Japan.
}

Received February 9, 2007

SYNOPSIS

Soft magnetic composites (SMC) have attracted a growing interest since they have the positive points in isotropic magnetic properties and high electric resistivity. They also have the advantage in fabricating complex shape products easily. In this experiment, water atomized iron powder with phosphate insulator coating around its surface was mixed with binder and three kinds of SMC specimens were prepared. The first one is prepared without binder (Sample A), the second one is prepared by using silicon resin as binder (Sample C), and the third one by using thermosetting polyimide (Sample D). In addition, the water atomized iron powder with $\mathrm{MgO}$ insulator coating (Sample B) was used, where the silicon resin and Bi-B system glass with low-temperature melting point were used as binder. Using these four kinds of samples, their corrosion behavior were investigated by electrochemical method. In the active zone, Sample D indicated the highest corrosion resistance due to the prevention of anodic reaction. It is because the added thermosetting polyimide prevents the penetration of corrosion solution into the sample. On the other hand, in the passive zone, Sample B showed the highest corrosion resistance due to the formation of uniform passive state film with good quality. It is because the added $\mathrm{Bi}-\mathrm{B}$ system glass prevents both grain separation and exposure of newly-formed surface to corrosion solution.

\section{KEY WORDS}

soft magnetic composite, magnetic characteristic, corrosion resistance, corrosion mechanism, polarization curve

\section{1 緒言}

粉末冶金材を代表する材料に $\mathrm{Fe}-\mathrm{Cu}-\mathrm{C}$ 焼結材が上げられ る、 $\mathrm{Fe}-\mathrm{Cu}-\mathrm{C}$ 焼結材の添加元素である $\mathrm{Cu}, \mathrm{C}$ は, 機械的強度 を上昇させ, 特にCuは寸法調節という特異な効果を材料に与 える.また，自動車部品や電子機器部品等において，従来の 鋳造材, 鍛造材に代わり, 粉末冶金材である $\mathrm{Fe}-\mathrm{Cu}-\mathrm{C}$ 焼結材 が広く使用されている。このように，粉末冶金は $\mathrm{Fe}-\mathrm{Cu}-\mathrm{C}$ を 中心として生産量を増加させている.一方では, 粉末に新しい 付加価值を付ける研究が進んでいる ${ }^{1-4)}$. 本研究の対象とする 複合軟磁性材料 (Soft Magnetic Composite 以降SMC 之略記) も その1つである，産業の高度化により，鉄損の小さいSMCが 高性能なモ一ター, 発電機等の電気駆動の機械への応用を目
的として要求されている.さらにSMCは, 絶縁皮膜を有する 純鉄粉に樹脂を混合し成形, 熱硬化させた材料で, 現在求め られている省エネルギー, 環境保護の要請にも対応できる. また，従来用いられているケイ素鋼板製の材料と比較して， 三次元的に成形可能であり, 高周波数側での磁気特性に優れ ている.このことから, 従来のコア材と比較して鉄損が小さ く抑えられる点で注目をされている ${ }^{5-7) . ~}$

ここで, SMC製品を実用化するためには，製品寿命を大き く左右する重要な因子の1つである耐食性の確認が要望され ている.しかしながら, SMCの耐食性の研究はほとんど行わ れていないのが現状である. そこで本研究では塞環境中にお ける車の排気ガスおよび海水の影響を想定し, $\mathrm{Na}_{2} \mathrm{SO}_{4}$ 水溶液 
と $\mathrm{NaCl}$ 水溶液を用いて分極曲線の測定を行うとともに, SEM による表面観察および断面観察を行い, SMCの腐食特性を調 査することを目的とした．

\section{2 試料および実験方法}

2.1 試料

本実験で用いた試料は，それぞれ構造が異なるSample A, B, $\mathrm{C}, \mathrm{D}$ の 4 種類の SMC 使用した. リン酸鉄で絶縁皮膜処理を 施した平均粒径 $80 \mu \mathrm{m}$ の純鉄粉を純窒素中 $773 \mathrm{~K}$ で熱処理し た Sample A, MgO を用いて絶縁皮膜処理を施した純鉄粉に， $\mathrm{Si}$ 系無機バインダーとしてシリコーンレジンおよびBi-B系低 融点ガラスを添加し, 純窒素中 $873 \mathrm{~K}$ で熱処理した Sample B, リン酸鉄を用いて絶縁皮膜処理を施した純鉄粉に, $\mathrm{Si}$ 系無機 バインダーとしてシリコーンレジンのみを添加し, 純窒素中 $873 \mathrm{~K}$ で熱処理した Sample C，リン酸鉄で絶縁皮膜処理を施 し，有機樹脂バインダーとして熱硬化性ポリイミドを添加し， 純窒素中 $573 \mathrm{~K}$ で熱処理した Sample Dである。なお，本実験 で用いた試料はすべて圧縮成形圧力 $784 \mathrm{MPa}$, 成形温度 $423 \mathrm{~K}$ の条件で成形した。

これらの耐食性を調查する為, 反応面を2000番の耐水エメ リ一紙を用いて湿式研磨し, 速やかにエチルアルコールで洗 浄した. その後アセトン中で $300 \mathrm{~s}$ 間超音波洗净し, 電極棒に 固定, 反応面積 $1 \times 10^{-4} \mathrm{~m}^{2}$ を残してシリコンラバーで絶縁処 理したものを試料電極として電気化学的腐食試験に用いた.

\section{2 分極曲線の測定}

SMCの基本的腐食特性を調査する目的で分極曲線を測定し た. Fig.1に分極曲線を測定する実験装置を示した. 本測定シ ステムは恒温槽中にアノード室とカソード室からなる $2.0 \times$ $10^{-4} \mathrm{~m}^{-3}$ の $\mathrm{H}$ 型電解槽, 中間槽, $\mathrm{Ag} / \mathrm{AgCl}\left(3.33 \mathrm{kmol} \cdot \mathrm{m}^{-3} \mathrm{KCl}\right)$ 照合電極, ブリッジおよび塩橋によって構成さ机ている. 試 料電極, 白金電極および照合電極はポテンショスタットに接 続されている. パーソナルコンピュータによりポテンショス タットを制御し，測定結果を自動記録した，なお，本論文の 電位は全て $\mathrm{Ag} / \mathrm{AgCl}$ 照合電極電位を基準として示した.

試験溶液には， $0.5 \mathrm{kmol} \cdot \mathrm{m}^{-3} \mathrm{Na}_{2} \mathrm{SO}_{4}$ 水溶液之 $0.5 \mathrm{kmol} \cdot \mathrm{m}^{-3}$

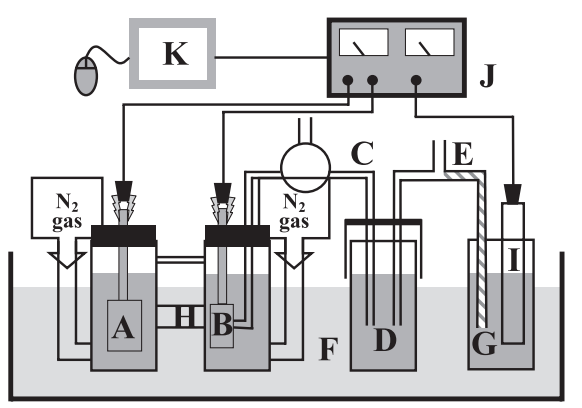

A:Counter electrode(Pt), B:Specimen, C:Bridge, D:Intermediate beaker E:Salt bridge, F:Water bath, G:Saturated potassium chloride solution, H:Electrochemical cell, I:Reference electrode, J:Potentiostat, K:Computer

Fig.1 Schematic diagram of apparatus for the electrochemical measurement.
$\mathrm{NaCl}$ 水溶液の2種類を用いた. これらの溶液は試験前に恒温 槽中で $298 \mathrm{~K}$ に保持し，純窒素ガスを用いてバブリングを行 ない，脱酸素を行なった，その後，試料電極を試験溶液に浸 漬し, $1.8 \mathrm{ks}$ 間保持した後, ポテンショスタットを用いて $1.5 \mathrm{~V}$ から $0.5 \mathrm{~V}$ まで, および-1.5Vから $2.0 \mathrm{~V}$ までの電位範囲を電 位插引速度 $5.0 \times 10^{-4} \mathrm{~V} \cdot \mathrm{s}^{-1}$ で順次電位を貴の方向に掃引し，そ の時の電流密度を自動記録した。

\section{3 定電位腐食試験および組織観察}

各試料の腐食形態を調べるため, $0.5 \mathrm{kmol} \cdot \mathrm{m}^{-3} \mathrm{Na}_{2} \mathrm{SO}_{4}$ 水溶 液を用い，電位を $0 \mathrm{~V}$ に規制し，定電気量のアノード電流を 流した。溶液は予め恒温槽中で $298 \mathrm{~K}$ に保持し, 純窒素ガス で十分に脱酸素を行なった。試験溶液に試料電極を浸漬し, ポテンショスタットを用いて, $0 \mathrm{~V}$ に定電位規制し, クーロ ンメーターにて流れる電気量を測定した. 電極面に $1 \mathrm{MC} \cdot \mathrm{m}^{-2}$ の定電気量を通電させ，腐食量を一定にした. 試験後にSEM を用いて各試料の表面および断面の組織観察を行った.まず, 基準として各試料の腐食前の表面観察を行なった。 次に, 定 電位腐食試験後の試料の表面および断面の観察を行なった。 定電位腐食試験後の表面観察认定電位腐食試験後の試料をア セトン中で $300 \mathrm{~s}$ 間超音波洗浄し, 乾燥後にSEM観察を行なつ た. また, 定電位腐食試験後の断面観察を行なうにあたって, 定電位腐食試験後の試料を切断し, 樹脂に埋め込んだ. その 後, 試料の断面を2000番の耐水エメリ一紙を用いて湿式研磨 し，速やかにエチルアルコールで洗净した，さらに，エチル アルコール中で $300 \mathrm{~s}$ 間超音波洗浄し, 乾燥後に SEM で観察 した.これら，定電位腐食試験後の表面および断面の観察した。

\section{3 実験結果および考察}

3.1 分極曲線

$3.1 .10 .5 \mathrm{kmol} \cdot \mathrm{m}^{-3} \mathrm{Na}_{2} \mathrm{SO}_{4}$ 水溶液中における分極曲線結果

SMCのカソード反応およびアノード反応の基本的特性を調 べるために各試料の分極曲線を測定した. Fig. 2 には $0.5 \mathrm{kmol} ・$ $\mathrm{m}^{-3} \mathrm{Na}_{2} \mathrm{SO}_{4}$ 水溶液中における分極曲線を示した. 縦軸が電位 を示しており,横軸は各電位における電流密度の対数値を示し

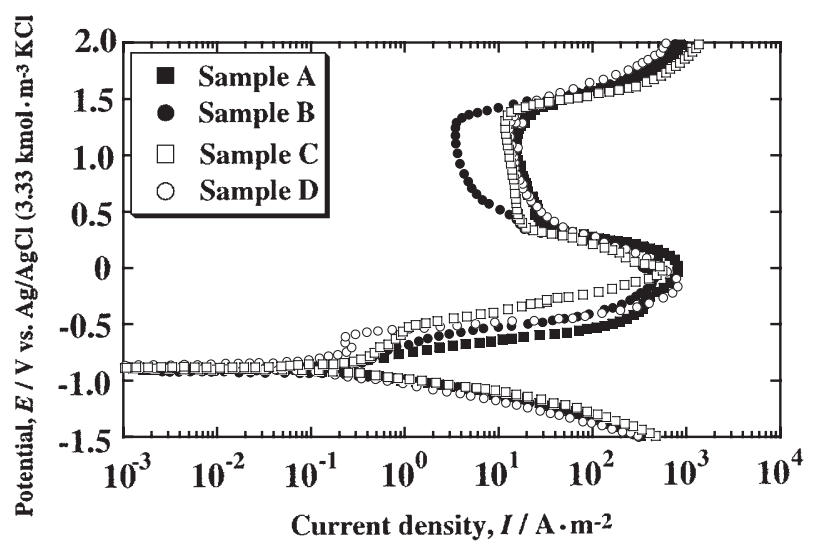

Fig.2 Anodic polarization curves of soft magnetic composite measured in $0.5 \mathrm{kmol} \cdot \mathrm{m}^{-3} \mathrm{Na}_{2} \mathrm{SO}_{4}$ solution at $298 \mathrm{~K}$. 
ている. 各試料の分極曲線は, 自然浸漬電位 ( 以後 $E_{\text {corr }}$ 上略 記)を境界としてカソード領域とアノード領域に分けられる. カソード領域は, 電位 $-0.9 \mathrm{~V}$ 以下の領域で示されている. この領域では, $-1.2 \mathrm{~V} か ら-1.0 \mathrm{~V}$ までが夕ーフェル勾配を表 す範囲であり，この範囲においていずれの試料ともに，夕一 フェル勾配の傾きがほぼ等しく, 電流密度の大きさも酷似し ている.また，実験中に試料電極を観察したところ， $\mathrm{H}_{2}$ の発 生が確認できた.つまり，カソード領域ではいずれの試料に おいても， $\mathrm{H}_{2}$ 発生型のカソード反応が同規模で起こってい る.なお, ターフェル勾配とは, 電位が電流密度の対数と比 例関係が成立して示される直線の傾きを意味する. その電位 範囲における反応機構に直線の傾きが一義的に対応すると考 えられている.すなわち, いずれの試料ともにターフェル勾 配に違いがない場合, この電位範囲では反応の種類が同じで あることを意味している。

ここで, $\mathrm{Na}_{2} \mathrm{SO}_{4}$ 水溶液中における各試料の基本的な腐食特 性をとらえるために, 夕ーフェル外挿法を用いて自然浸漬時 の腐食速度を表す腐食電流密度 (以後 $I_{\text {corr }}$ と略記) を求め, 活 性態領域における, みかけの腐食速度を求めた. Sample Aの 場合は, $E_{\text {corr }}-0.890 \mathrm{~V}$ の電位において, $I_{\text {corr }}$ の值は $0.16 \mathrm{~A} \cdot \mathrm{m}^{-2}$ であった. Sample Bの場合は, $E_{\text {corr }}-0.917$ Vの電位において, $I_{\mathrm{cor}}$ の值は $0.37 \mathrm{~A} \cdot \mathrm{m}^{-2}$ であった. Sample Cの場合は, $E_{\mathrm{oor}}-0.915 \mathrm{~V}$ の電位において， $I_{\text {corr }}$ の值は $0.64 \mathrm{~A} \cdot \mathrm{m}^{-2}$ であった. Sample D の場合は, $E_{\mathrm{cor}}-0.863 \mathrm{~V}$ の電位において, $I_{\mathrm{cor}}$ の值は $0.088 \mathrm{~A} \cdot \mathrm{m}^{-2}$ であった，次に得られた各試料の結果を用い, Fig.3に $I_{\text {corr }}$ に 及ぼす比抵抗の影響を示した。ここで，比抵抗は，各試料の 基本性能である.なお, 比抵抗はSMCの性能を示すパラメ一 夕で, 值が大きい方が高性能である。 I $I_{\text {corr }}$ に及ぼす比抵抗の影 響を見ると, 本実験の基準としたバインダ一を添加していな いSample A と比較して, Si 系無機バインダーを添加した Sample BおよびSample Cは比抵抗の対数值の増加に伴い, $I_{\text {corr }}$ がほぼ直線的に増加する傾向を示した. 比抵抗が10倍増加す

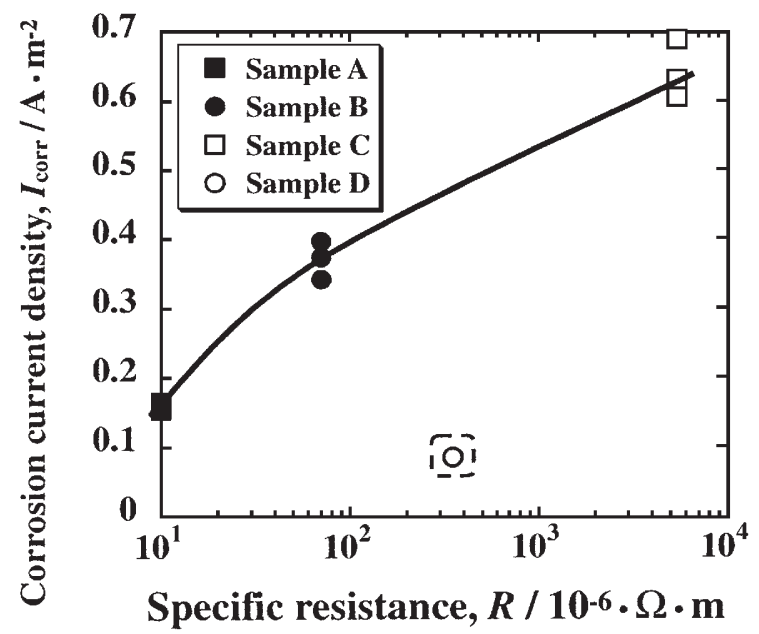

Fig.3 Influence of specific resistance on $I_{\text {corr }}$ of soft magnetic composite in $0.5 \mathrm{kmol} \cdot \mathrm{m}^{-3} \mathrm{Na}_{2} \mathrm{SO}_{4}$ at $298 \mathrm{~K}$.
ると, $I_{\mathrm{corr}}$ は約 $0.12 \mathrm{~A} \cdot \mathrm{m}^{-2}$ 增加し, $\mathrm{Si}$ 系無機バインダーを使 用した場合は, 性能向上に伴い腐食速度の増加が生じること が判明した。一方, 有機樹脂バインダ一を添加した Sample D の場合, 比抵抗は Sample Aの35倍であるが, $I_{\text {corr }}$ の值は 0.088 $\mathrm{A} \cdot \mathrm{m}^{-2}$ とSample Aよりも小さな值を示した.このように有機 樹脂バインダーを添加した場合, 性能の向上に伴い腐食速度 が減少することが判明した，そこで, この電気化学的要因を 調べるためFig.4に示した $E_{\text {corr }}$ に及ぼす比抵抗の影響を確認す ると, 基準とした Sample A の $E_{\text {corr }}$ の值は-0.89V を示した. 既報 ${ }^{8)}$ の純鉄粉の示す $E_{\text {corr }}$ と類似しており, SMC中の主成分 であるFeが腐食挙動に強く関わっていると考えられる.これ に対し，Si 系無機バインダーを添加した Sample B および Sample Cの $E_{\text {cort }}$ は-0.02 V 低下する傾向を示した.つまり, Si 系無機バインダ一を添加した場合は, 性能の向上とともに腐 食速度が増加する．この腐食速度の増加は，アノード反応が 促進することに起因していると考えられる. 一方, Sample D の場合, $E_{\text {corr }}$ はS Sample Aの $E_{\text {corr }}$ と比較して $0.04 \mathrm{~V}$ 高い值を示 した. 有機樹脂バインダーを添加した場合は, 基準とした Sample Aよりも $I_{\mathrm{corr}}$ は低下し， $E_{\text {corr }}$ が上昇していた。これは, アノード反応が抑制されることを意味し，有機樹脂バイン ダーを添加した場合, 性能が向上し, 同時に耐食性が向上す るという非常に魅力的な性質が判明した.

いずれの試料においても不動態を示す領域は $-0.2 \mathrm{~V}$ から $1.3 \mathrm{~V}$ までの範囲であった.この領域において Sample B は $0.4 \mathrm{~V}$ から $1.3 \mathrm{~V}$ の範囲で著しく小さな值を示した.そこで, 不動態 領域の腐食速度を確認する為に, $0.6 \mathrm{~V}$ における電流密度をパ ラメータとして, 比較, 検討した. Fig.5には Fig.2 中の電位 $0.6 \mathrm{~V}$ における電流密度に及ぼす比抵抗の影響を示した. 各試 料の電位 $0.6 \mathrm{~V}$ における電流密度の值は, Sample Aの場合 25.9 $\mathrm{A} \cdot \mathrm{m}^{-2}$, Sample Bの場合 $7.3 \mathrm{~A} \cdot \mathrm{m}^{-2}$, Sample $\mathrm{C}$ の場合 $24.0 \mathrm{~A} \cdot \mathrm{m}^{-2}$, Sample Dの場合 $15.9 \mathrm{~A} \cdot \mathrm{m}^{-2}$ であった.このことから, Sample $\mathrm{B}$ は他の 3 種類と比較して, 最も大きな差として約 $30 \%$ に抑

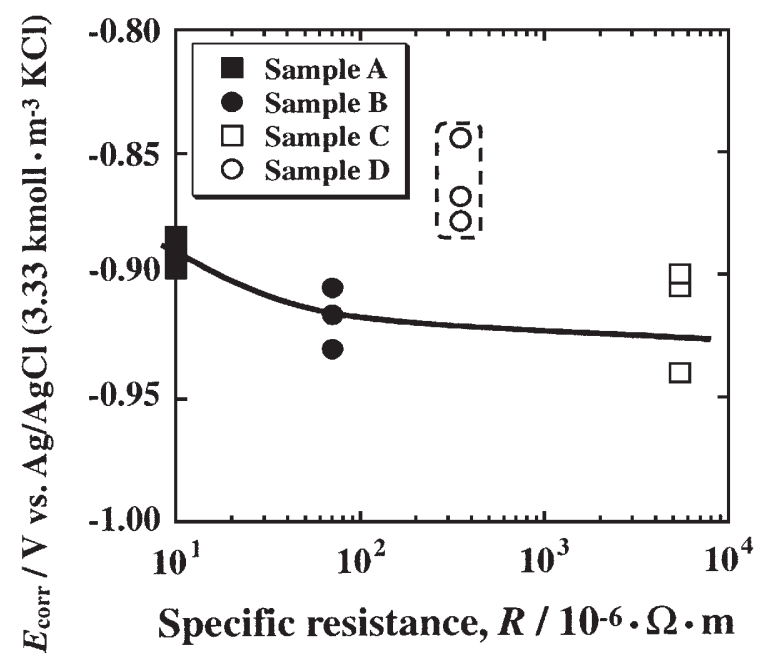

Fig.4 Influence of specific resistance on $E_{\text {corr }}$ of samples in 0.5 $\mathrm{kmol} \cdot \mathrm{m}^{-3} \mathrm{Na}_{2} \mathrm{SO}_{4}$ at $298 \mathrm{~K}$. 


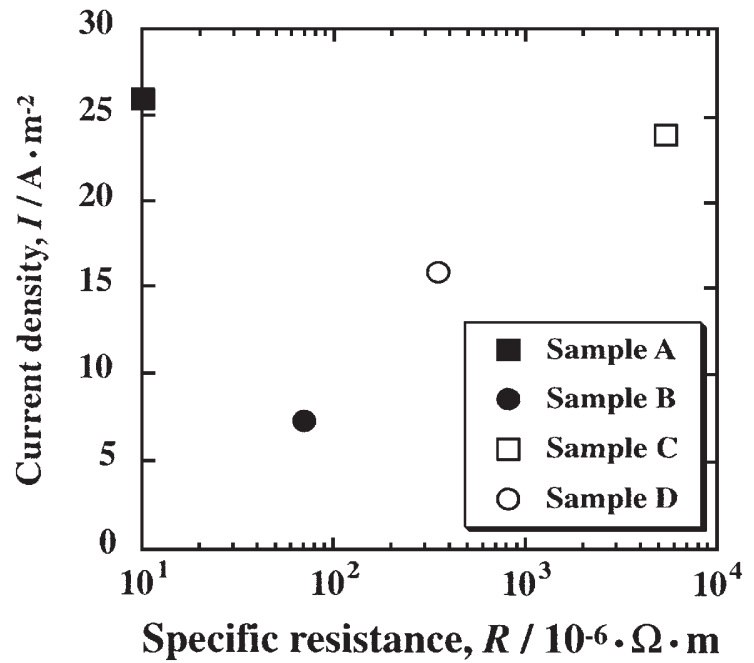

Fig.5 Influence of specific resistance on current density of samples in $0.5 \mathrm{kmol} \cdot \mathrm{m}^{-3} \mathrm{Na}_{2} \mathrm{SO}_{4}$ at $298 \mathrm{~K}$.

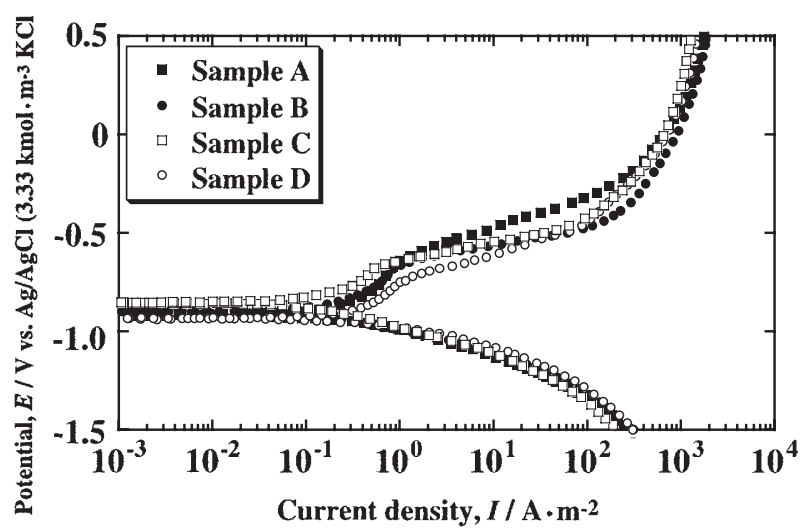

Fig.6 Anodic polarization curves of soft magnetic composite measured in $0.5 \mathrm{kmol} \cdot \mathrm{m}^{-3} \mathrm{NaCl}$ solution at $298 \mathrm{~K}$.

えられ，低い電流密度の值を示した．このことから，不動態 領域において Sample B の耐食性に対する有効性が明らかと なった。これは，Sample Bのみに使用されているBi-B系低 融点ガラスが起因していると考えられる.ここで, Bi-B系低 融点ガラスは, 後述する溶液の染み込みを防ぐことに作用す るものと考えている.

\section{$3.1 .20 .5 \mathrm{kmol} \cdot \mathrm{m}^{-3} \mathrm{NaCl}$ 水溶液中での分極曲線}

Fig.6には $0.5 \mathrm{kmol} \cdot \mathrm{m}^{-3} \mathrm{NaCl}$ 水溶液中における分極曲線を示 した.こちらの分極曲線も縱軸が電位を示しており，横軸は 各電位における電流密度の対数值を示している. 各試料の分 極曲線は， $E_{\text {corr }}$ を境界としてカソード領域とアノード領域に 分けられる.

カソード領域は, 電位 $-0.85 \mathrm{~V}$ 以下の領域で示されている. この領域では, $-1.2 \mathrm{~V}$ から-1.0Vまでがターフェル公配を表 す範同であり，この範囲においていずれの試料ともに, ター フェル勾配の傾きがほぼ等しく, 電流密度の大きさも酷似し

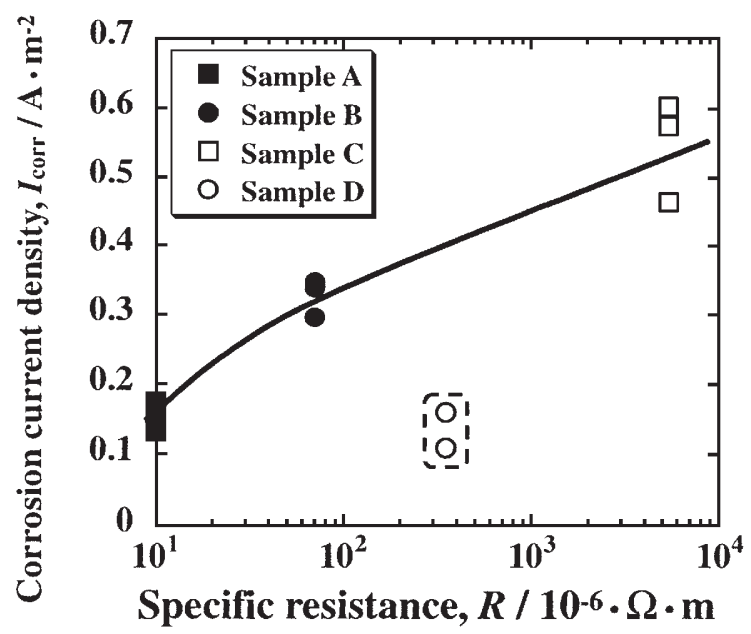

Fig.7 Influence of specific resistance on $I_{\text {corr }}$ of samples in $0.5 \mathrm{kmol}$. $\mathrm{m}^{-3} \mathrm{NaCl}$ at $298 \mathrm{~K}$.

ている. また，実験中に試料電極を観察したところ， $\mathrm{H}_{2}$ の発生 が確認できた。つまり，カソード領域ではいずれの試料にお いても， $\mathrm{H}_{2}$ 発生型のカソード反応が同規模で起こっている.

この分極曲線を見ると, $\mathrm{NaCl}$ 水溶液中では, Fig.2 に示し た $\mathrm{Na}_{2} \mathrm{SO}_{4}$ 水溶液中で作成した分極曲線とは異なり, 不動態領 域は確認できなかった。 これは, $\mathrm{NaCl}$ 水溶液中の塩化物イ才 ンにより, 安定な不動態皮膜が形成できなかった為であると 考えられる ${ }^{9,10)}$.

ここで, $\mathrm{NaCl}$ 水溶液中においても各試料の基本的腐食特性 を詳細に調查する目的で, ターフェル外挿法を用い $I_{\mathrm{cor}}$ を算出 し, みかけの腐食速度を求めた. Sample Aの場合は $E_{\mathrm{corr}}-0.913 \mathrm{~V}$ の電位で, $I_{\text {corr }}$ の值は $0.155 \mathrm{~A} \cdot \mathrm{m}^{-2}$ であった. Sample Bの場合 は $E_{\text {corr }}-0.927 \mathrm{~V}$ の電位で, $I_{\text {corr }}$ の值は $0.327 \mathrm{~A} \cdot \mathrm{m}^{-2}$ であった. Sample Cの場合は $E_{\text {corr }}-0.929 \mathrm{~V}$ の電位で, $I_{\text {corr }}$ の值は 0.547 $\mathrm{A} \cdot \mathrm{m}^{-2}$ であった. Sample Dの場合は $E_{\text {corr }}-0.870 \mathrm{~V}$ の電位で, $I_{\text {corr }}$ の值は $0.126 \mathrm{~A} \cdot \mathrm{m}^{-2}$ であった。 そこで, $\mathrm{Na}_{2} \mathrm{SO}_{4}$ 水溶液を用 いた場合と同様に，得られた各試料の結果を用い, Fig.7に $\mathrm{NaCl}$ 水溶液中における各試料の $I_{\text {corr }}$ に及ぼす比抵抗の影響を 示した.ここで, 比抵抗は, 各試料の基本性能である. なお, 比抵抗はSMCの性能を示すパラメータで, 值が大きい方が高 性能である. $I_{\text {corr }}$ に及ぼす比抵抗の影響を見ると, 本実験の基 準としたバインダーを添加していない Sample A と比較して, Si 系無機バインダーを添加した Sample B および Sample C は 比抵抗の対数值の増加に伴い, $I_{\text {corr }}$ がほぼ直線的に増加する傾 向を示した. 比抵抗が 10 倍増加すると, $I_{\text {corr }}$ は約 $0.15 \mathrm{~A} \cdot \mathrm{m}^{-2}$ 増加し, Si 系無機バインダーを使用した場合は, 性能向上に 伴い腐食速度の増加が生じることが判明した。一方, 有機樹 脂バインダーを添加した Sample Dの場合, 比抵抗はSample A の 35 倍であるが, $I_{\text {corr }}$ の值は $0.109 \mathrm{~A} \cdot \mathrm{m}^{-2}$ と Sample A よりも 小さな値を示した.このように有機樹脂バインダーを添加し た場合, 性能の向上に伴い腐食速度が減少することが判明し た. そこで,この電気化学的要因を調べるためFig.8に示した, 
$\mathrm{NaCl}$ 水溶液中における各試料の $E_{\mathrm{corr}}$ に及ぼす比抵抗の影響を 確認すると, 基準とした Sample A の $E_{\text {corr }}$ の値はー0.91 V を示 した.こちらも，既報 ${ }^{8}$ の純鉄粉の示す $E_{\mathrm{corr}}$ と類似しており， $\mathrm{SMC}$ 中の主成分である Feが腐食挙動に強く関わっていると 考えられる.これに対し，Si 系無機バインダーを添加した Sample BおよびSample Cの $E_{\text {corr }}$ は-0.02V低下する傾向を示 した.つまり, Si 系無機バインダーを添加した場合は, 性能 の向上とともに腐食速度が増加する.この腐食速度の増加は, アノード反応が促進することに起因していると考えられる. 一方, Sample Dの場合, $E_{\text {corr }}$ は Sample A の $E_{\text {corr }}$ と比較して $0.04 \mathrm{~V}$ 高い值を示した. 有機樹脂バインダ一を添加した場合 は，基準とした Sample A よりも $I_{\text {corr }}$ は低下し， $E_{\text {corr }}$ が上昇し ていた.これは,アノード反応が抑制されることを意味し, 有 機樹脂バインダーを添加した場合，性能が向上し，同時に耐 食性が向上するという非常に魅力的な性質が判明した。これ らの得られた結果は $\mathrm{Na}_{2} \mathrm{SO}_{4}$ 水溶液を用いた場合と同じ傾向を 示した.つまり, $\mathrm{NaCl}$ 水溶液中においても $\mathrm{Si}$ 系無機バイン ダ一の添加により，性能の向上とともに腐食速度が増加し， それは，アノード反応の促進に起因していると考えられる. 一方，有機樹脂バインダーを添加したSample Dの場合は，ア ノード反応の抑制によって耐食性が向上していると考えられ る. 従って, $\mathrm{Na}_{2} \mathrm{SO}_{4}, \mathrm{NaCl}$ どちらの水溶液環境中においても, 活性態域では, Sample Dは性能の向上と共に耐食性が向上す る性質を示すことが明らかとなった。

3.2 定電位腐食試験および組織観察

3.2 .1 定電位腐食試験後の表面観察

上述した分極曲線の結果から, 本実験で用いた試料の中で
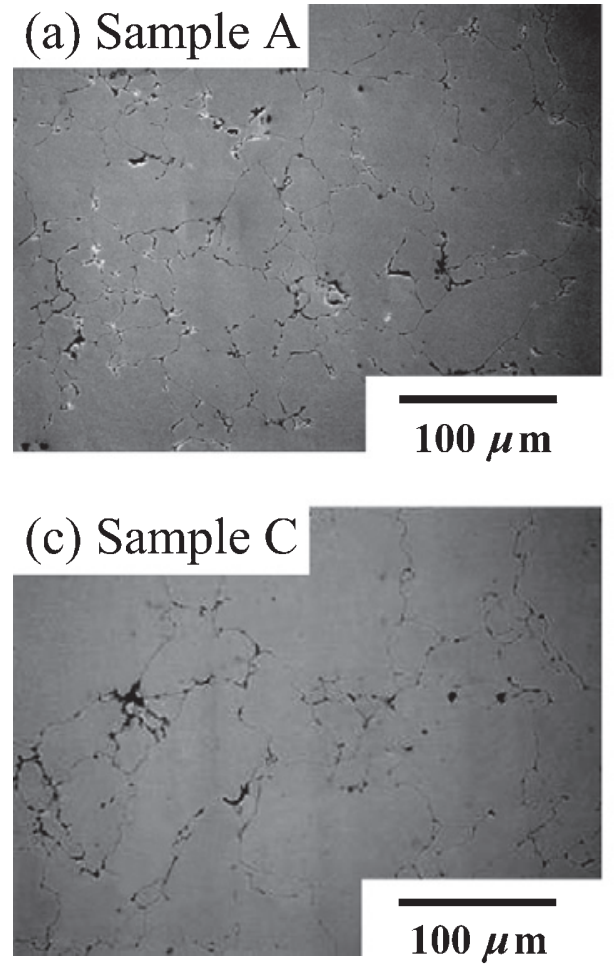

活性態領域における耐食性は, 有機樹脂バインダーである熱 硬化性ポリイミドを添加したSample Dで, 不動態領域におけ る耐食性は, 絶縁皮膜として MgOを, $\mathrm{Si}$ 系無機バインダーで あるシリコーンレジンおよび Bi-B系低融点ガラスを添加した Sample Bで, それぞれ最も良い性質を示した. その要因を各試 料の腐食後の組織から確認するためSEMによる観察を行った.

Fig.9には本実験の基準とした腐食前の表面観察結果を示し た. Fig.9(a)が Sample Aを, Fig.9(b)がSample Bを, Fig.9(c) が Sample Cを, Fig.9(d)が Sample Dをそれぞれ示している.

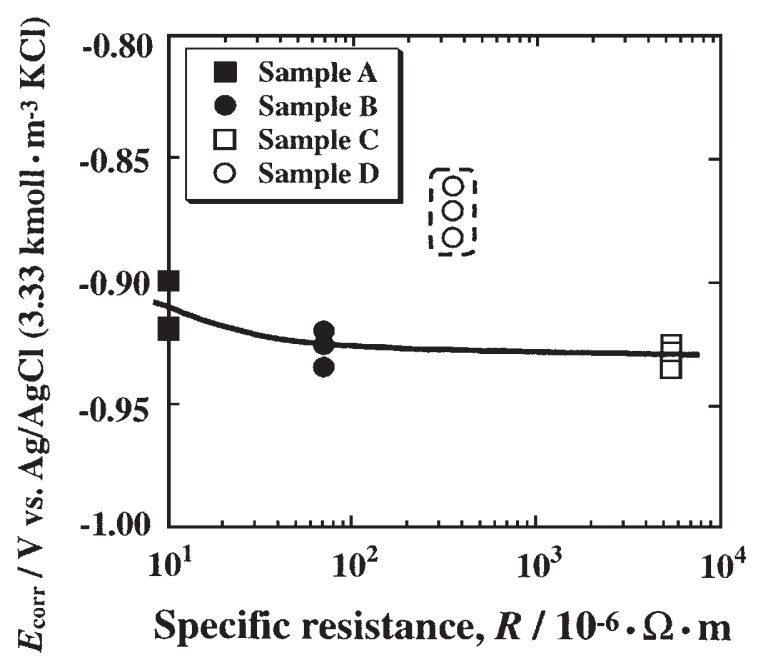

Fig.8 Influence of specific resistance on $E_{\text {corr }}$ of samples in 0.5 $\mathrm{kmol} \cdot \mathrm{m}^{-3} \mathrm{NaCl}$ at $298 \mathrm{~K}$.
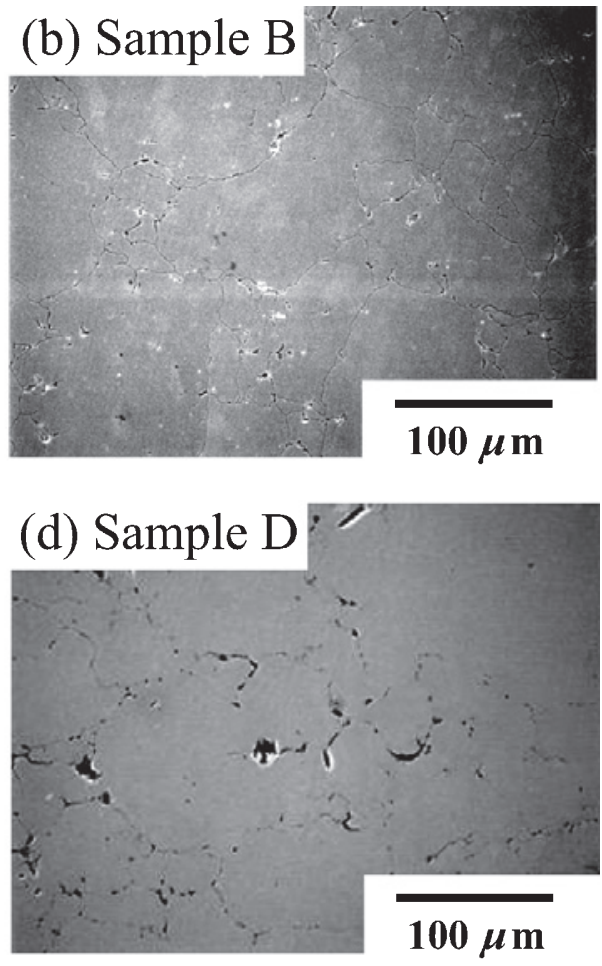

Fig.9 SEM micrographs on the surfaces section of the specimen. 
いずれの試料においても特徵として粉末が勘合することによ り成形されているのが確認できる. 特に Sample B はBi-B 系 低融点ガラスの効果で勘合隙間が小さくなっていることが確 認できる.

Fig. 10 には $0.5 \mathrm{kmol} \cdot \mathrm{m}^{-3} \mathrm{Na}_{2} \mathrm{SO}_{4}$ 水溶液中において, 活性態 域である電位 $0 \mathrm{~V}$ に定電位規制し, 各試料を活性態域におけ る $0 \mathrm{~V}$ に規制し, $1 \mathrm{MC} \cdot \mathrm{m}^{-2}$ の電気量を通電させ一定のダメ一 ジを与えた試料の表面観察写真を示した.いずれの試料にお いても勘合の隙間における激しい腐食が確認できる。また， Sample A, Sample C, Sample D の場合，鉄粉粒子自体の腐食 および粒子の脱粒が確認できた. 一方, Sample B の場合, 腐 食形態が他の試料とは異なっており，脱粒が少なく，それに より新生面の露出が小さく抑えられていると考えられる。こ のことから, 表面状態を均一に保つことのできるSample Bの みで均一な不動態皮膜を形成でき, 不動態領域において良好 な耐食性が得られたと考えられる。この要因の 1 つとして, Sample Bに絶縁皮膜として使用されているMgOと低融点ガラ スの効果であると考えられる.すなおち, Sample A, Sample C, Sample Dでは，鉄粉粒子の大規模な溶解が見られることか ら,リン酸皮膜が鉄粉粒子の溶解を促進する働きがあるもの と考えられる. 一方, Sample Bでは, 鉄粉粒子の勘合部分が 優先して溶解していることから, MgOは鉄粉粒子に保護作用 を持ち, 見かけ上の溶解が小規模に抑えられている.さらに 低融点ガラスの作用で, 脱粒が押さえられ，新生面の露出が 少ないものと考えられる.

\section{2 .2 定電位腐食試験後の断面観察}

上述した分極曲線の結果では，活性態領域において有機樹
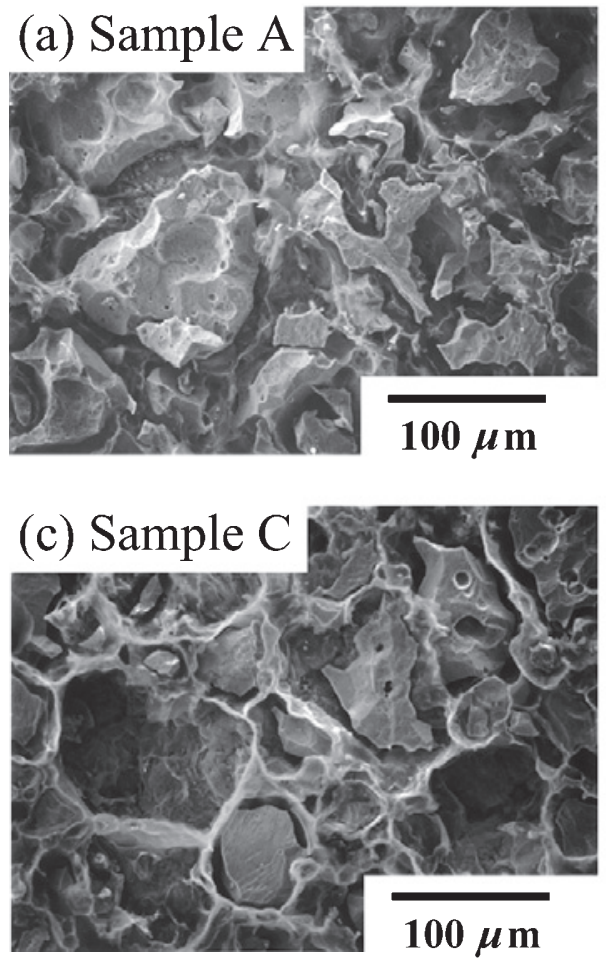

脂バインダーである熱硬化性ポリイミドを添加したSample D が最も良好な耐食性を示した。同じ活性態域である電位 $0 \mathrm{~V}$ に定電位規制を行い, 表面観察を行った結果では, 絶縁皮膜 として MgO, 無機バインダーであるシリコーンレジンおよび Bi-B 系低融点ガラスを添加した Sample B が最も良好な耐食 性を示した.この相反した結果が得られた要因を解明するた めに, 深さ方向の腐食を確認するため, 各試料の断面観察を 行った. Fig.11 には定電位腐食試験後の各試料の断面観察結 果を示した. Fig.11 (a)が Sample A を, Fig.11 (b) が Sample B を, Fig.11 (c)がSample Cを, Fig.11 (d)が Sample Dをそれぞ れ示している. 各写真において上部が腐食面であり, 深さ方 向の腐食は下方向である. Sample A, Sample Cの場合, 表面 の腐食に加えて内部への液の浸透により縦方向の腐食が進行 していることが確認できた. Sample B の場合, 表面状態は良 好に保たれていたが，内部への液の浸透により，縱方向の腐 食が進行していることが確認できた。 この要因によって, 基 淮とした Sample A と比較してアノード反応が複極し， $I_{\text {corr }}$ の 值は比較的大きな値を示したと考えられる. 一方, Sample D の場合, 溶液の内部への浸透が抑制できていることが確認で きた. この要因として, バインダーとして添加されている熱 硬化性ポリイミドの効果があると考えられる.このような浸 透の抑制によりアノード反応面積が基準としたSample A と比 べて減少すると考えられる，故に，アノード反応が分極し， $I_{\text {corr }}$ の值は非常に小さく押さえられていたと考えられる.以上 のことからSMCの腐食特性は勘合による結合状態が密接に 関係していると考えられ, 特に勘合隙間を通した, 深さ方向 の腐食については注意が必要であることが明らかとなった。
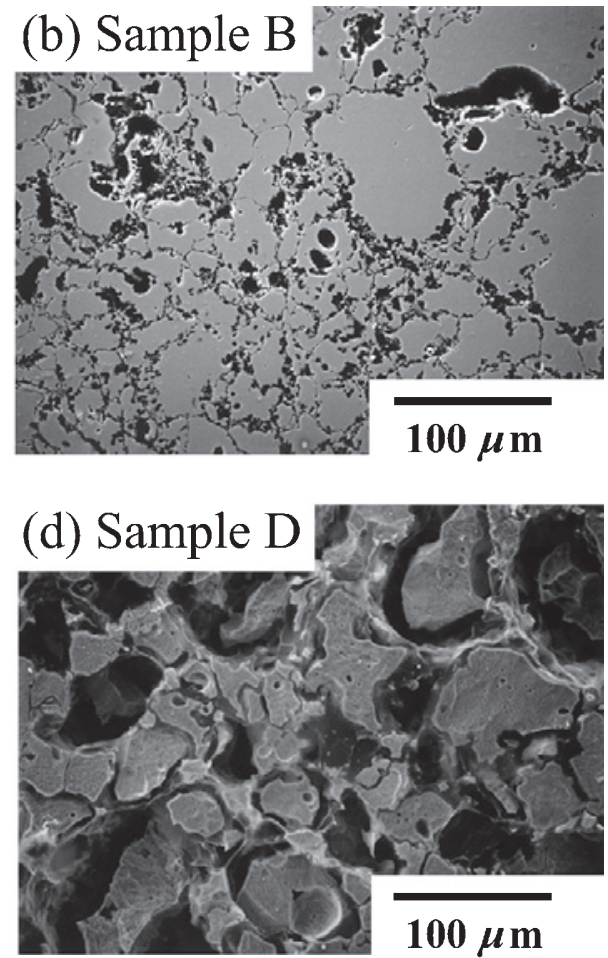

Fig.10 SEM micrographs on the surfaces section of the specimen after constant potential corrosion test in $0.5 \mathrm{kmol} \cdot \mathrm{m}^{-3} \mathrm{Na}_{2} \mathrm{SO}_{4}$ at $298 \mathrm{~K}$. 

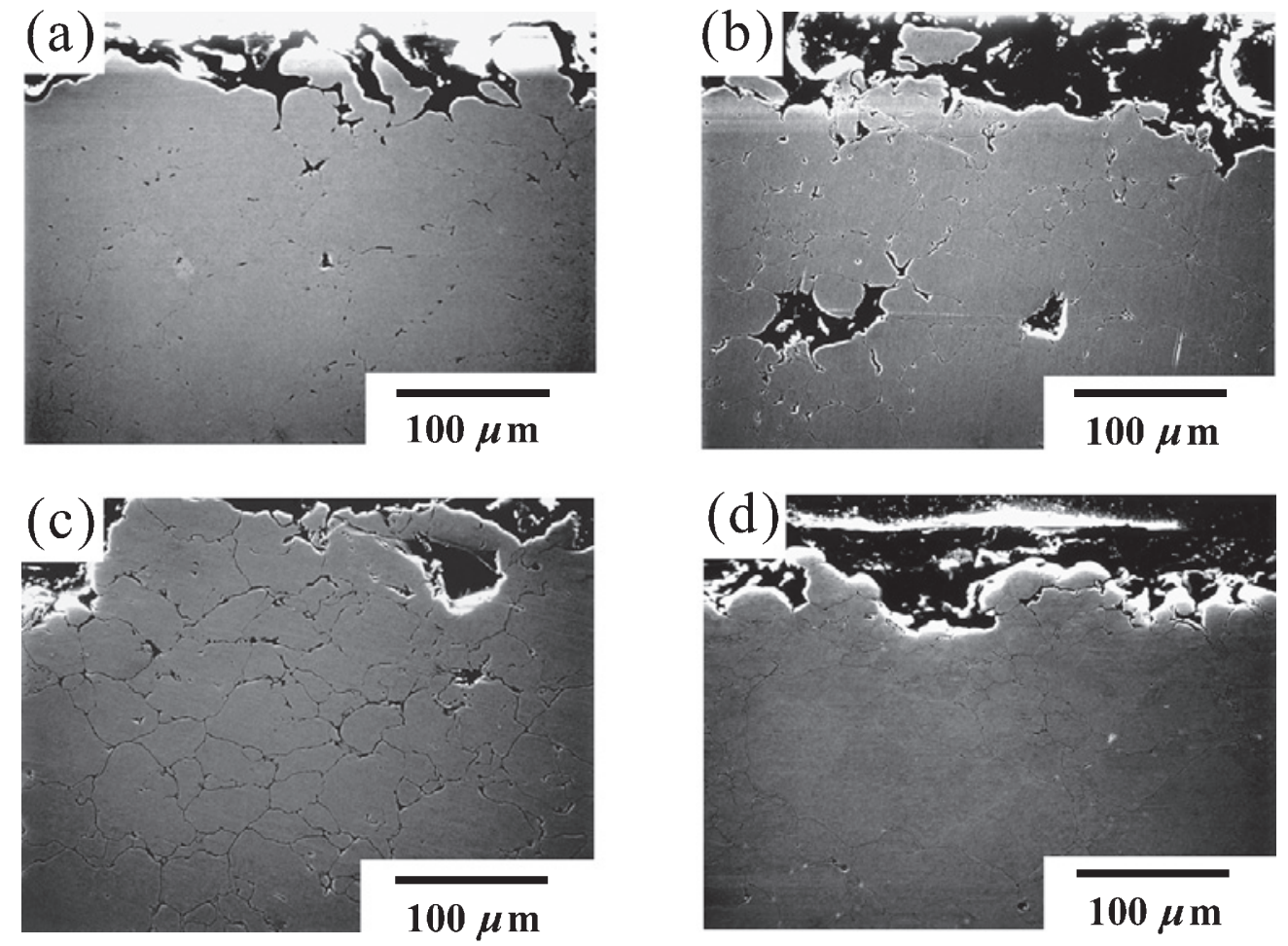

Fig.11 SEM micrographs on the cross sectionof the specimen after constant potential corrosion test in $0.5 \mathrm{kmol} \cdot \mathrm{m}^{-3} \mathrm{Na}_{2} \mathrm{SO}_{4}$ at $298 \mathrm{~K}$. $($ a) $=$ Sample A (b) = Sample B (c) $=$ Sample C $(d)=$ Sample D

\section{4 ま と め}

実環境を想定し, $\mathrm{Na}_{2} \mathrm{SO}_{4}$ 水溶液, $\mathrm{NaCl}$ 水溶液中で $\mathrm{SMC}$ の 耐食性の評価を行った. その結果をまとめると次のようになる.

(1) 分極曲線の結果及びSEMによる組織観察の結果より, 活 性態領域では有機樹脂バインダ一(熱硬化性ポリイミド) の添加により試料内部への溶液の浸透が抑制でき，ア ノード反応が抑制でき耐食性が向上する.

(2) 分極曲線の結果及びSEMによる組織観察の結果より, 不 動態領域ではBi-B系低融点ガラスの添加により粒子の脱 粒が抑制でき，新生面の露出が少なく，均一で良好な不 動態皮膜が形成でき，酎食性が向上する.

(3) SMCの腐食特性には, 勘合による結合状態が密接に関係 しており，特に深さ方向の腐食に注意が必要である.

\section{文献}

1) S.J.Jamil and G.A.Chadwick: "Inverstigation and analysis of liquid phase sintering of $\mathrm{Fe}-\mathrm{Cu}$ and $\mathrm{Fe}-\mathrm{Cu}-\mathrm{C}$ compacts", Powder metallurgy, 28(1985)65-71.

2) N.Dautzenberg and H.J Dorweiler: "Dimensional behavior of Copper-Carbon sintered steel", Powder metallurgy international, 17(1985)279-282.

3) J.Tanaka and N.Kawai: "Dimensional change during sintering of iron based powders", Powder metallurgy, 38(1995)209-213.
4) G.Anthory and M.Randall: "DIMENSIONAL CONTROL IN THE SINTERING OF IRON-COPPER-CARBON VIA PARTICLE SURFACE AREA", The International Journal of Powder Metallurgy, 30(1994)399-409.

5) G.Uozumi, M.Watanabe, R.Nakayama, K.Igarashi and K.Morimoto: "Properties of Soft magnetic Composite with Evaporated MgO Insulation Coating for low Iron loss", Materials Science Form, 534-536(2007)1361-1364.

6) R.Nakayama, M.Watanabe, G.Uozumi, K.Igarashi and K.Morimoto: "Magnetic Properties of Lower Core Loss Soft Magnetic Composites Made from Heat Resistance MgO Insulation Coated Iron Powders", J. Jpn. Soc. Powder Powder Metallurgy, 53(2006)285-289.

7) M.Masuzawa, M.Mita, K.Kikuchi and K.Aimuta: "Dual Mold Magnet Rotor for Permanent Magnet Motors", Hitachi Metals Technical Review, 22(2006)35-40.

8) K.Kanno, S.Sunada, K.Majima, M.Ishida and Y.Takeda: "Electrochemical Characteristics of Fe-Cu-C Sintered Steels", J. Jpn. Soc. Powder Powder Metallurgy, 53(2006)661-666.

9) G.Itou: Corrosion Science and Engineering, CORONA PUBLISHING CO., LTD., (1979)23-25.

10) H.H.Uhlig and R.W.Revie: Corrosion and Corrosion Control, SANGYOUTOSYO PUBLISHING CO., LTD., (1968)318-322. 